(C)2014

НЕОЛИТИЧЕСКИЕ КРЕМНЕВЫЕ АНСАМБЛИ БОЛГАРИИ: ОБЗОР ПРОБЛЕМЫ

М. Гюрова, кандидат наук, доцент

Институт археологии и музей НАН Болгарии, София (Болгария)

Аннотаџия: Статья содержит краткий обобщайщий обзор кремневых ансамблей неолитического периода в Болгарии (VI тыс. до н.э.). Прослеживается их эволюция, которая в зависимости от контекста имеет разные проявления и может быть названа по разному - инновация или трансформация. В течение неолита обнаружены некоторые существенные изменения, которые касаются всех аспектов кремневой индустрии: происхождения, добычи и использования кремневого сырья; технико-типологические параметры индустрии; функциональные характеристики отдельных категорий артефактов. Основное проявление этих изменений состоит в микролитизации индустрий. Эмпирическая база исследования состоит из колекций, происходящих с 18 неолитических поселений. Выявленны особенности эволюционного развития кремневых ансамблей из теллей и отмечены отличия по сравнению с коллекциями из кратковременных обьектов иного предназначения. На базе широкой основы представленного материала в статье в форме дискуссии сформулированы некоторые существенные вопросы относительно нашего знания и осмысления неолитического образа жизни.

Ключевые слова: неолит; кремневые ансамбли; характерные типы орудий; микролитизация; Балканский кремень.

УДК 902.2

ПАЛЕОЭКОЛОГИЧЕСКИЕ УСЛОВИЯ ОБИТАНИЯ ПЛЕМЕН ЭПОХИ НЕОЛИТА И (C)2014 ЭНЕОЛИТА В ПЕСКАХ ВОЛГО-УРАЛЬСКОГО МЕЖДУРЕЧЬЯ

И. В. Иванов, доктор географических наук

Институт физико-химических и биологических проблем почвоведения РАН, Пущино (Россия)

И.Б. Васильев, кандидат исторических наук, доцент кафедры отечественной истории и археологии Поволжская государственная сочиально-гуманитарная академия, Самара (Россия)

Аннотация: В статье представлена реконструкция палеоэкологических условий по древним почвам, отложениям, данным палинологии и палеозоологии. Природа развитого и позднего неолита соответствовала современной полупустыне, эпохи энеолита - более влажным сухим степям. Развитие ландшафтов и общества в Рын-песках на протяжении голоцена было прерывисто-дефляционным, неоднократно прерываясь периодами кризисов аридизации с активными эоловыми процессами.

Ключевые слова: неолит; энеолит; палеоэкология; палеопочвы; прерывисто-дефляционное развитие природы и общества.

Реконструкция палеоэкологических условий и влияния природных условий прошлых эпох на жизнь древних обществ - актуальные вопросы археологии и древней истории, палеогеографии и палеопочвоведения. Территория Рын-песков - удобный объект для таких реконструкций. Работа подготовлена И.В. Ивановым по материалам книги: И.В. Иванов, И.Б. Васильев «Человек, природа и почвы Рын-песков Волго-Уральского междуречья в голоцене» [1]. Археолог Игорь Борисович Васильев (1948-2004) является полноправным соавтором данной статьи, несмотря на то, что его сегодня нет с нами.

Общая характеристика территории. Рынпески расположены в низовьях рек Волги и Урала в Прикаспийской низменности. Большинство исследователей относят современные Рын-пески к ландшафтам полупустынной зоны с бурыми пустынно-степными почвами под лишайниково-злаково-полынной псаммофитной растительностью, некоторые - к ландшафтам пустынь. Исследовался модельный участок квадратной формы 100x100 км со стороной между селами Сеитовка - Тамбовка вдоль реки Ахтуба. Большая часть модельного участка расположена ныне в Астраханской области РФ, другая, меньшая - в Атыраусской области республики Казахстан.

Современный климат - сухой, континентальный с коротким весной и осенью (по 1,5-2 месяца) и длительным летом и зимой. Количество атмосферных осадков 120 150 мм, испаряемость около 1000 мм, средние температуры июля $+25^{\circ}$, января $-8^{\circ}$, года $+7^{\circ}$. Осадки часто имеют ливневой характер, снежный покров неустойчивый, в отдельные зимы образуются снежный наст, ледовая корка, приводящие к гибели животных (явление «джут»).

На протяжении голоцена за 11500 лет континентального развития в Рын-песках сменилось, чередуясь, 14 различных климатических эпох (по подзональной принадлежности) со следующей их суммарной длительно- стью в годах и увлажненностью: степные и сухостепные - 4,1 тыс. лет (4 эпохи), 36\% времени, осадков 400-500 и 200-400 мм/год: полупустынные - 3,5 тыс. лет (5 эпох), 30\% времени, осадков 150-200 мм/год; пустынные - 2,4 тыс. лет (4 эпохи), 21\% времени, 100-150 мм/год; перигляциальные - 1,5 тыс. лет (2 эпохи), 13\% времени

Рельеф Рын-песков - волнисто-равнинный, средняя высота над уровнем мирового океана $-10,-11$ м (современный уровень Каспийского моря - 26 м). Распространены протяженные понижения с солончаками; эоловые котловины различных размеров и глубин. В наиболее активных котловинах встречаются многочисленные грибовидные эоловые останцы - столбы, до 3 м высоты и 1 м ширины. Амплитуда колебаний мезорельефа в целом составляла преимущественно около 5 м (до 10 м). Пески богаты пресными грунтовыми водами, расположенными в понижениях на глубинах 2-3 м.

Мелкозернистые пески и супеси, слагающие поверхность, исходно имеют морское и аллювиальное происхождение, полевошпатово-кварцевый состав (полевых шпатов 8-23\%). Полимиктовость песков благоприятствует почвообразованию.

На большей части территории пески неоднократно перевеяны. В среднем в половине почвенных разрезов глубиной более 1,5 м (из двухсот разрезов) встречаются почвы, погребенные эоловыми песками. Большинство археологических памятников обнаружены благодаря дефляции, по этой же причине памятники имеют разную сохранность. Перевевание и переотложение песков происходило в аридные эпохи, почвообразование - в более влажные климатические эпохи. Из общего числа местонахождений с археологическим материалом (183) объекты с относительно сохранившимися культурными слоями и погребенными почвами составляют $11 \%$ от их числа. Относительно лучше сохранились культурные слои эпохи неолита ( $20 \%$ от местонахождений) и хуже 
- культурные слои эпох бронзы и раннего железа (5\%)

Почвы и растительность. Современные закрепленные пески заняты лишайниково-злаково-белополынными ассоциациями на бурых пустынно-степных почвах. Джузгун и колосняк способны долго и эффективно закреплять эоловые останцы. Из древесных пород распространены тополь, ивы, лох узколистный, вяз, они бывают обвиты лианой ломонос.

Палеоиндикаиия природных условий прошлых эпох по погребенным песчаным почвам в сравнении их $c$ современными. Несмотря на слабую выраженность почвообразования на песках, имеющиеся различия между почвами достаточны для палеоиндикации условий природной среды по погребенным песчаным почвам. Характерное время их формирования и достижения зрелого состояния почвенных профилей (100-200-300 лет) обеспечивает индикацию условий почвообразования за относительно короткие промежутки времени. Приведем характеристику современных целинных песчаных почв по собственным данным и материалам других исследователей $[2 ; 3 ; 4 ; 5 ; 6 ; 7 ; 8]$.

Дерново-степные черноземовидные песчаные почвы сформировались под типчаково-разнотравно-ковыльной растительностью. Годовые осадки/ ис паряемость, мм/год: 400-500/650-800, t января $-9 \ldots-13^{\circ}$, t июля $+21 \ldots+22^{\circ}$. Строение профиля: АО 3 см (здесь и далее - глубина нижней границы горизонтов, см) - A1 у ,Z, 40 см - AB j, Z $80 \mathrm{~cm}-\mathbf{B}$ z,hf, $140 \mathrm{~cm}-\mathbf{B C}$ яз, $180 \mathrm{~cm}-\mathbf{C}$, $>200$ см. Характерные черты горизонтов - обильные $(Z)$ и менее обильные (z) следы мезофауны, слабая оструктуренность гор. А1, раздельно частичность в остальных горизонтах, бледные гумусово- железистые пленки на песчаных зернах (hf), затечность, языковатость (яз) нижней границы горизонта, отсутствие вскипания от $\mathrm{HC} 1$ - промытость от $\mathrm{CaCO}_{3}$ и водорастворимых солей, нейтральная реакция среды по всему профилю, гуматный гумус в гор. А

Дерново-степные каштановидные песчаные почвы под полынно-типчаковой растительностью. Годовые осадки/испаряемость 200-400/800-1000 мм/год, t января $-8 \ldots-11, \mathrm{t}$ июля $+25 \ldots+27$. Строение профиля: $\mathbf{A ~ j , ~} \mathbf{z}$, яз, $30 \mathrm{~cm}-\mathbf{A B ~ z}$, яз , $50 \mathrm{~cm}-\mathbf{B} \mathrm{z}, \mathrm{ca}, 80 \mathrm{~cm}-\mathbf{B C}$ CA, $140 \mathrm{~cm}$ - C ca , $200 \mathrm{~cm}$.

Каштановидные почвы сходны с черноземовидными по окраске и гумусированности, составу гумуса, однако в составе гумуса они содержат больше фульвокислот. Горизонты имеют меньшие мощности, нижние их границы в см: А - 30, АВ - 50, Вса - 80, ВСса - 140 см. Признаки слабой агрегированности отмечены только в гор. А. Из-за меньшего промачивания (непромывной и периодически промывной режим) в гор. В и ВС отмечается слабое карбонатонакопление (до 4-5\% $\mathrm{CaCO}_{3}$ ). В гор. В наблюдается едва заметное накопление окислов железа. Затечность отмечена в гор. АВ и В. Затечность имеет трещинно-биогенное происхождение (образование трещин во влажной почве при промерзании и их проработка при проникновении в них корней).

Бурые пустынно-степные песчаные почвы обладают многими признаками нормальных суглинистых почв. Годовые осадки/испаряемость 150-200/1000-1200 мм/год, $\mathrm{t}$ января $-7 \div 10^{\circ}, \mathrm{t}$ июля $+25 \ldots 27^{\circ}$. Строение профиля : $\mathbf{A}$, яз, 20 см - В са, яз $50 \mathrm{~cm}-$ ВC са, 140 см - C , $200 \mathrm{~cm}$.

Гумусонакопление ничтожное (в гор. А до 0,4\%), состав гумуса гуматно-фульватный, окраска бледносветлосерая, агрегированность отсутствует, карбонато накопление биогенное ослабленное, карбонатные прожилки и трубочки по ходам корней в гор.В и ВС (1-0,8\% $\mathrm{CaCO}_{3}$ ). На песчаных зернах в гор.В и ВС имеются в табл.1 кальцитовые и гумусово-железистые пленки. Лессиваж отсутствует, очень бледная ржавая окраска в гор. В - результат слабого протекания процесса рубефикации в окислительной обстановке. Солонцеватость у бурых песчаных почв не выражена. Реакция среды по профилю слабощелочная в гор. А и В, щелочная в гор. Самарский научный вестник. 2014. № 3(8)
ВС и С. Профиль промыт от легкорастворимых солей.

Таблица

Свойства современных связнопесчаных полевошпатово-кварцевых почв

\begin{tabular}{|c|c|c|c|c|c|c|c|c|c|c|c|c|c|c|}
\hline \multirow{3}{*}{$a^{3}$} & \multirow{2}{*}{\multicolumn{4}{|c|}{$\begin{array}{l}\text { Зоны } \\
\text { Типы почв } \\
\end{array}$}} & \multicolumn{10}{|c|}{ Черноземностепная } \\
\hline & & & & & \multicolumn{5}{|c|}{ Дерново-боровые } & \multicolumn{5}{|c|}{ Черноземовидные } \\
\hline & Гори & 130нT1 & & & $\mathrm{AO}$ & $\mathrm{A}$ & $\mathrm{Bfe} 3$ & $\mathrm{BC}$ & $\mathrm{C}$ & $\mathrm{A}$ & \begin{tabular}{|l|l|}
$\mathrm{AB}$ & $\mathrm{B}$ \\
\end{tabular} & $\mathrm{BC}$ & $\mathrm{C}$ & \\
\hline 4 & \multicolumn{4}{|c|}{ Нижняя граница, см } & 5 & 20 & 60 & 90 & 100 & 40 & \begin{tabular}{|l|l|}
80 & 140 \\
\end{tabular} & 180 & & 80 \\
\hline 5 & \multicolumn{4}{|c|}{$\mathrm{pH}$} & 5,5 & 6,0 & 6,9 & 7,1 & 7,1 & 6,5 & \begin{tabular}{|l|l|}
6,7 & 7,0 \\
\end{tabular} & 7,0 & &, 0 \\
\hline 6 & \multirow{2}{*}{\multicolumn{4}{|c|}{\begin{tabular}{|l|} 
Гумус, \% \\
Емкость погл., мг-экв \\
$/ 100$ г
\end{tabular}}} & $1-2$ & 0,5 & 0,1 & 0,03 & 0,01 & $1-2$ & \begin{tabular}{|l|l|}
0,7 & 0,3 \\
\end{tabular} & 0,2 & & 1 \\
\hline 7 & & & & & 10 & 4,2 & 3 & 1,6 & & 5,5 & \begin{tabular}{|l|l|}
3,5 & 2,5 \\
\end{tabular} & 1,5 & &, 5 \\
\hline 8 & \multirow{2}{*}{\multicolumn{4}{|c|}{\begin{tabular}{|l|} 
Вскипание от НC1, см \\
СаCO3\%
\end{tabular}}} & \multirow{2}{*}{\multicolumn{5}{|c|}{\begin{tabular}{|l} 
отсутствует \\
отсутствут
\end{tabular}}} & \multicolumn{5}{|c|}{\begin{tabular}{|l|} 
отсутствует \\
\end{tabular}} \\
\hline 9 & \multirow{2}{*}{\multicolumn{4}{|c|}{\begin{tabular}{|l|} 
СаCO3,\% \\
Сумма солей, \%; тип хи \\
мизма водной вытяжки
\end{tabular}}} & & & & & & \multirow{2}{*}{\multicolumn{5}{|c|}{\begin{tabular}{|l|} 
отсутствует \\
Менее 0,$01 ; \mathrm{HCO} 3-\mathrm{Ca}$ \\
\end{tabular}}} \\
\hline 10 & & & & & \multicolumn{5}{|c|}{ Менее 0,$01 ; \mathrm{HCO} 3-\mathrm{Ca}$} & & & & & \\
\hline 11 & \multirow{2}{*}{\multicolumn{4}{|c|}{\begin{tabular}{|l|} 
Ходы мезофауны \\
Затеки-языки \\
\end{tabular}}} & \multirow{2}{*}{\multicolumn{5}{|c|}{ В гор. AO, A, B }} & \multicolumn{5}{|c|}{ Обильны в гор. А, AB, В } \\
\hline 12 & & & & & & & & & & \multirow{2}{*}{\multicolumn{5}{|c|}{\begin{tabular}{|l} 
В гор B и BC \\
в гор. А и AB \\
\end{tabular}}} \\
\hline 13 & & \multicolumn{5}{|c|}{ В гор. АО и $\mathrm{A}$} & & & & & \\
\hline 14 & \multicolumn{4}{|c|}{$\begin{array}{l}\text { Содержание фракций, } \% \\
\text { менее } 0,001 \text { мм } \\
\text { менее } 0,01 \text { мм } \\
0,25-0,05 \text { мм }\end{array}$} & & \begin{tabular}{|l}
1 \\
2 \\
70 \\
\end{tabular} & $\begin{array}{l}1 \\
2 \\
78\end{array}$ & & & & 6 & & & \\
\hline 15 & \multicolumn{4}{|c|}{ Тип водного режима } & \multicolumn{5}{|c|}{ промывной } & \multicolumn{5}{|c|}{$\begin{array}{l}\text { Промывной или } \\
\text { периодически промывной }\end{array}$} \\
\hline 1 & \multicolumn{5}{|c|}{ Каштановостепная } & \multicolumn{4}{|c|}{ Полупустынная } & Пуст & тынная & & & \\
\hline 2 & Кашт & танов & идные & & & \begin{tabular}{|l} 
Бурыс \\
Степн
\end{tabular} & $\begin{array}{l}\text { iе пусти } \\
\text { ные }\end{array}$ & ынно- & & & тынные & & & \\
\hline$\overline{3}$ & A & $\mathrm{AB}$ & $\mathrm{Bca}$ & BCca & $\mathrm{C}$ & $\mathrm{A}$ & Bca & $\mathrm{BCca}$ & $\mathrm{C}$ & (Eol) & \begin{tabular}{l|l} 
1) & (Kca)
\end{tabular} & $\mathrm{AE}$ & $\mathrm{A}$ & $\mathrm{B}$ \\
\hline 4 & 30 & 50 & 80 & 140 & 200 & 20 & 50 & 40 & 200 & $1-5$ & 1 & & 5 & 30 \\
\hline 5 & 7,5 & 8,0 & 8,0 & 8,0 & & 年 & 7,6 & 8 & 8,3 & $=$ & 8 & 8 & 9 & 10 \\
\hline 6 & 0,7 & \begin{tabular}{|l|}
0,4 \\
\end{tabular} & 0,3 & 0,2 & 0,1 & 0,3 & 0,2 & 0,1 & 0,1 & 0,1 & 0,5 & 0,6 & & \\
\hline 7 & 4,5 & 3,0 & 2 & 1,5 & 1 & 6 & 4,5 & 5 & 6 & & & & & \\
\hline 8 & & & $0-150$ & & & & $20-14$ & & & по вс & сему профи & & & \\
\hline 9 & 0 & 0 & $1-2$ & $4-5$ & 0,5 & 0,5 & 1,0 & 0,8 & 0,2 & 4 & 9 & 7 & 5 & 6 \\
\hline 10 & Мене & 0,1 & $\mathrm{HCO} 3$ & $-\mathrm{Ca}$ & & $\begin{array}{l}\text { Мене } \\
\mathrm{Cl}-\mathrm{Na}\end{array}$ & $\mathrm{a}, \mathrm{N}$ & $\mathrm{HCO}_{3}$ & & Мене & ree $0,1 \mathrm{Cl}$ - & $\mathrm{Na}$ & $\mathrm{Mg}$ & \\
\hline 11 & Слаб & бые в & op. A, & $\mathrm{AB}, \mathrm{Bca}$ & & Оченг & ьь слабо & ое в гор & & \begin{tabular}{|l|} 
отсут \\
\end{tabular} & Тствуют & & & \\
\hline 12 & Очен & нь сла & бая в гс & op. AB, $\mathrm{F}$ & & В гор. & Bca & & & в гор. & & & & \\
\hline 13 & \begin{tabular}{|l|}
3 \\
5 \\
57
\end{tabular} & \begin{tabular}{|l}
3 \\
5 \\
53
\end{tabular} & $\begin{array}{l}3 \\
5 \\
52\end{array}$ & $\begin{array}{l}3 \\
5 \\
58\end{array}$ & & \begin{tabular}{|l|}
6 \\
12 \\
85
\end{tabular} & \begin{tabular}{|l|}
4 \\
6 \\
89
\end{tabular} & \begin{tabular}{|l|}
3 \\
4 \\
92
\end{tabular} & & & & & & $\begin{array}{l}5 \\
10\end{array}$ \\
\hline 15 & $\begin{array}{l}\text { Hепр } \\
\text { пери } \\
\text { nром }\end{array}$ & $\begin{array}{l}\text { ромыв } \\
\text { родиче }\end{array}$ & ной, & & & $\begin{array}{l}\text { Непрс } \\
\text { перио }\end{array}$ & оди & тром & & пр & apr & & & \\
\hline
\end{tabular}

Пустынные песчаные почвы (пескоземы пустыннble - по Лаврову, 1979) под песчаноосоковой растительностью со мхами и лишайниками. Годовые осадки/ испаряемость: 100-150/1200-2000 мм/год, t января -2... $7^{\circ}, \mathrm{t}$ июля $+27 \ldots+30^{\circ}$. Строение профиля: (Eol, ca), 1-5 см - (K CA), 1 см - AE CA , 5 cm - A CA, $15 \mathrm{~cm}-\mathbf{B}$ , СА $30 \mathrm{~cm} \mathrm{-} \mathrm{C,} \mathrm{СА,} 50$ см. С поверхности может присутствовать маломощный перевеваемый эоловый нанос или пористая карбонатная корочка, под ними чешуйчатый гор. AЕ СА. Органическое вещество присутствует в незначительном количестве в виде детрита в верхних слоях, условия для гумификации создаются лишь на некотором отдалении от поверхности (А CA, В CA). Карбонатонакопление атмо-биогенное, формы карбонатов дисперсные, новообразования практически отсутствуют. В гор. В наблюдаеся слабое покраснение (рубефикация). Почвенные зоны-подзоны заметно отличаются по биологической продуктивности растительного покрова. Подземная биомасса превышает надземную в 5-6 раз. Экосистемы относятся к пастбищному типу. Фитомасса потребляется млекопитающими - грызунами и копытными животными. В целинных экосистемах (без участия домашних животных) фитопродукция, поедаемая консументами, в среднем составляет до $50 \%$. В зависимости от погодных условий и колебаний численности животных поедаемая фитомасса может колебаться от 30 до $80 \%$. Средняя продуктивность песчаных пастбищ для копытных животных (50 \% поедаемой фитомассы, с учетом доли грызунов) колеблется по подзонам следующим образом, в ц/га/год: в черноземных степях - около 14, в каштановых степях - 8,5, полупустынях - 6,0, пустынях умеренного пояса - 5,0 ц/га/год или, принимая продуктивность пастбищ современных полупустынь за 1: 2,33-1,41-1,0-0,8.

Животные и их роль в экосистемах. Самыми многочисленными млекопитающими современных Рынпесков являются мелкие подвижные растительноядные грызуны - гребенчуковая и полуденная песчанки (последняя - природный резервуар чумы, переносчик 
блохи), с плотностью 10-30 и более экз./га [9]. Высокой численностью отличается и крупный желтый суслик (до 7 экз/га) [10]. Обитают также заяц-русак, хищники - лисица-корсак, обыкновенная лисица, степной хорь, ласка, орлы, совы, луни, редко встречаются (встречались) волки [11]. Из диких копытных млекопитающих в Рынпесках в настоящее время обитают только сайгак (до 50000 голов в 1980-1990 г.г.), до середины 19 века были широко распространены тарпаны. По свидетельству Эверсмана, в 1820-1840 гг. на их многотысячные стада уральскими казаками ещё велась интенсивная охота и отлов.

Авторами предложен способ ориентирочной оценки численности диких и домашних животных и численности населения Он основан на идее Б.Д. Абатурова о примерном равенстве биомасс экологических групп животных на единицу площади $[12 ; 1]$, на представлениях о доле поедаемой ими фитопродукции, о плотности археологических памятников на 100 лет археологической эпохи и некоторых других допущениях.

Особенности экологических условий, предшествовавших эпохе неолита. Эпохе неолита предшествовал период континентального развития территории в течении около 3500 лет, после отступления моря, совпадающий с мезолитом, древним и ранним голоценом. По изменению природных условий этот период может быть предположительно разделен на эпохи - этапы.

1) Мариевый прибрежно-морской этап, от примерно 11500 лет назад на протяжении десятилетий - первых столетий. Условия были мало благоприятными для обитания людей и животных. 2) Перигляцииальнокриоаридныцй этап, примерно 11-10 т.Л.н., по-видимому, совпадавший с мангышлакской регрессией Каспийского моря, периодом DR-3 и характеризовавшийся интенсивными дефляционными процессами (стадия афитогенной дефляции по А.Г. Гаелю.

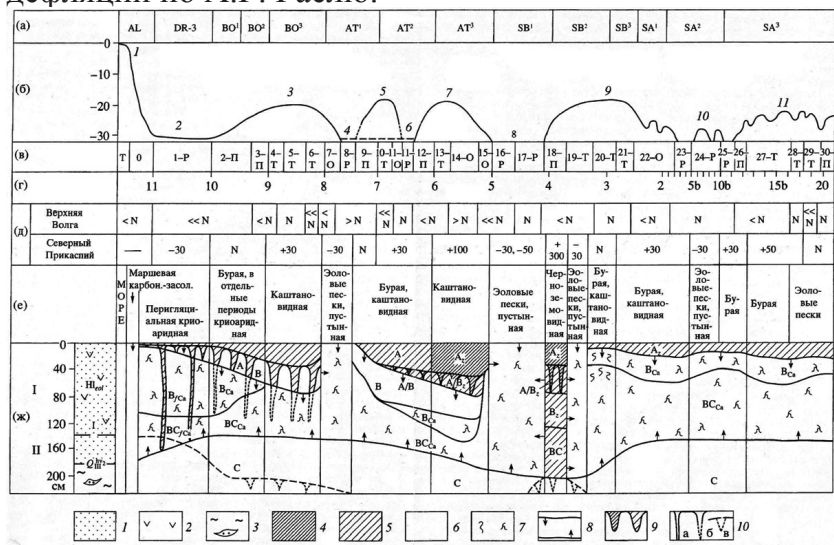

Рис. 1. Колебания уровня Каспийского моря

и изменение природных условий в его бассейне

a - Подразделение голоцена на периоды: AL - аллеред, ВК-3 - поздний дриас, ВО - бореальный, АТ - атлантический, SB - суббореальный, SA - субатлантический. б - колебания уровня Каспийского моря, м. Регрессии: 2 - мангышлакская, 4 - «а», 6 - «в», 8 - махачкалинская, 10 - дербентская. Трансгрессии: 1 - позднехвалынский бассейн, 3 - дагестанская, 5 - «б», 7 - гоусанская, 9 туралинская, 11- позднедербентская. в - ХY и их номера. г - шкала абсолютного возраста, тыс. лет назад и века до н.э. д - атмосферные осадки (АО) относительно нормы $\mathrm{N}$ над территорией Верхней Волги - $(\mathrm{N},>\mathrm{N}$, $<\mathrm{N},<<\mathrm{N})$ и Северного Прикаспия $(<<\mathrm{N}(-30 \ldots-50 \mathrm{Mм})$, $<\mathrm{N}(-30),>\mathrm{N}(+30 \ldots+100),>>\mathrm{N}(+300)) . \mathrm{e}-$ типы почв Северного Прикаспия в различные периоды голоцена. ж - I. Литологическая колонка: 1 - песок мелкозернистый, 2 - ракушечный детрит, 3 - морские шоколадные глины с линзами песка. II. Изменения свойств почв. Цвет почв: 4 - серый и темно-серый, 5 - светло-серый, 6 - темно-, светло-желтый, желтый. Новообразования: 7 - прожилки карбонатных солей, 8 - зона сплошного вскипания от 10\%-ной $\mathrm{HCl}, 9$ - гумусовые языки и затеки, 10 мерзлотные клинья: а - «живущие», б - реликтовые, в остатки нижних частей клиньев в породе под эоловыми песками. Индексы почвенных горизонтов: Az, Bz - горизонты с обильными следами деятельности почвенной мезофауны; АВ - переходный горизонт без затеков; A/B - горизонт с затеками; Bca, ВСса - горизонты с аккумуляцией карбонатов; Bf, Cf - мерзлотные горизонты; $\mathrm{C}-$ порода.

3) Полупустынный, периодически периглящиальный этап с бурыми пустынно-степными почвами, 10-9 т.л.н., приходящийся на подъем уровня Каспийского моря от ниже -35 м до -20 м. 4) Этап сухостепной с каштановидными почвами (9-8 т.л.н.) характеризовался относительно удовлетворительными экологическими условиями для людей и животных.

Растительность. Считается, что первоначально на территории, освободившейся от моря, произрастали полыни, маревые, эфедра, возможно, сосна, а затем в составе растительного покрова постепенно увеличивалась доля злаковых, разнотравья, кустарничков [13].

Животный мир. По аналогии с мезолитическими памятниками Причерноморья и Средней Азии (по общим для них видам) можно предполагать обитание в Рын-песках сайгака, лисиц, волка, тура, кулана, плейстоценовой лошади, тарпана. Среди грызунов наиболее многочисленными были характерные пустынные виды - степная пеструшка, желтый суслик, гребенщиковая песчанка. Численность полуденной песчанки (носителя чумы) была незначительной [14].

Почвы эпохи мезолита. На памятнике Же-Калган-2 обнаружены хорошо сохранившиеся культурный слой и погребенная почва (р. 2 Досанг). Разрез расположен в активной эоловой котловине в обнажении холмика-останца высотой около 1,5 м (поперечник 1х2 м). Эоловый нанос-почва. 0-5 cм - светло-желтый барханный мелкозернистый некарбонатный песок. 5-50 см, желтый косослоистый эоловый песок послемезолитического времени, с прожилками карбонатов. Сложная погребенная почва. 0-180 см - различный песок, 180-260 см - «шоколадная» хвалынская глина. Формирование почвы завершилось в мезолите. Гор. А содержит мезолитические кремневые микролиты. Строение профиля мезолитической почвы: гор. A-30(см); гор. A/B-70; B/A -110; B-153; BC-190; C $\mathrm{Fe}^{3+}, \mathrm{CaCO}_{3}-235$; D $\mathrm{CaSO}_{4}-260$ см. Приведенной интерпретации соответствуют и материалы обследования близ расположенного памятника Же-Калган-3 [15].

Взаимодействие природы и общества. Известны 22 археологических памятника эпохи мезолита на территории модельного участка. Их плотность составляет 0,7 на 100 лет эпохи. В основном это скопления однородного археологического материала недавно развеянных местонахождений. Находки представлены микролитами из кремня. Встречены мелкие жженые косточками и фрагменты костей кулана [16]. Археологическая культура носит название сероглазовской [17].

Хозяйство было присваивающим - охота на куланов, сайгаков, птицу, собирательство. Можно предположить, что была распространена добыча рыбы при помощи гарпунов, лука и стрел. Мезолитическое население знало огонь.

Небольшие площади, занимаемые мезолитическими стоянками (их размеры не превышали в поперечнике 2030 м), относительно немногочисленный инвентарь, маломощность культурного слоя свидетельствуют о подвижном образе жизни, кратковременности функционирования стоянок, а также о небольших размерах групп мезолитических охотников, рыболовов, собирателей.

Рын-пески в неолите, энеолите - атлантическом периоде голоцена

В системе периодизации голоцена атлантическому периоду принадлежит важное место термического оптимума планетарного характера.

В пределах Восточно-Европейской равнины к северу от 60 с.ш. осадки были на 50-100 мм выше современСамарский научный вестник. 2014. № 3(8) 
ных, между 60 - 50-53ㅜ.ш. - были близки современным, южнее 50-53 - были выше их на 50-100 мм [18]. Значительно более высоким увлажнением (на 200-300 мм) характеризовались Средняя Азия и Сахара, где на месте современных пустынь располагались степи и саванны $[19 ; 20]$. Уровень мирового океана на протяжении атлантического периода постепенно и колебательно поднялся от -20 м до 0 м.

Колебания уровня Каспия. По данным Г.И.Рычагова (1993), АТ-период характеризовался двумя трансгрессиями длительностью 600 (7,3-6,6 т.л.н.) и `1200 лет (6,3-5,5 т.л.н.), разделенными более короткими по времени регрессиями. Другие исследователи [21;22] отрицают существование первой из трансгресий, считая, что уровень Каспия 7,7-6,4 т.л.н. был регрессивным.

Растительность $и$ климат Рын-песков. Палинологические данные характеризуют АТ-1, АТ-2 как теплую, относительно сухую эпоху с преобладанием полыней, маревых; $\mathrm{AT}^{3}$ - как более влажную (вначале теплую, затем - более прохладную) с участием злаков, разнотравья и частично древесных пород [23;13].

Животный мир. Из крупных млекопитающих в неолите преобладал кулан, несколько реже встречались сайгак и бизон, тур (крупный бык), лошадь (однако не тарпан, или лошадь Пржевальского, а вид, близкий по величине тела и пропорциям к уральской плейстоценовой лошади [16]. Размеры всех этих животных значительно крупнее более поздних экземпляров на смежных территориях, в том числе, кулан крупнее современных животных, обитающих в Туркменистане. В энеолите резко уменьшилась численность кулана и увеличилась численность сайгака. По мнению И.Е. Кузьминой, овца и лошадь имеют признаки одомашнивания, особенно для эпохи энеолита.

Экологические особенности животного мира Рынпесков раскрывают данные А.И.Дмитриева [14] (табл. 3). В АТ-периоде в сравнении с ВО, РВ увеличилось обилие степных видов грызунов и песчанок. Фауна атлантического времени формируется при активном участии и взаимодействии южно-европейских и среднеазиатских компонентов. Более высокое атмосферное увлажнение и обводнение котловин подтверждается нахождением на поселениях костей рыб, жаб и раковин пресноводных моллюсков. Малое распространение среди песчанок полуденных песчанок позволяет предположить, что эпидемиологическая обстановка по чуме в эпохи неолита и энеолита была более благоприятной, чем в последующее время.

Таблица 2 - Видовой состав млекопитающих на археологических памятниках (мин. число особей) в Рынпесках по данным изучения костных остатков [16]

\begin{tabular}{|c|c|c|c|c|c|c|}
\hline \multirow{3}{*}{$\begin{array}{l}\text { Виды млеко- } \\
\text { питаюших }\end{array}$} & \multicolumn{2}{|c|}{ Поздний неолит } & \multicolumn{4}{|l|}{ Энеолит } \\
\hline & \multirow{2}{*}{$\begin{array}{l}\text { Тентек- } \\
\text { Cop-1 }\end{array}$} & \multirow{2}{*}{$\begin{array}{l}\text { Же- } \\
\text { Калган-1 }\end{array}$} & \multicolumn{2}{|l|}{ развитой } & \multicolumn{2}{|l|}{ поздний } \\
\hline & & & $\begin{array}{l}\text { Курпеже- } \\
\text { Молла-1 }\end{array}$ & $\begin{array}{l}\text { Кара- } \\
\text { Худук }\end{array}$ & $\begin{array}{l}\text { Же- } \\
\text { Калган-1 }\end{array}$ & $\begin{array}{l}\text { Кызылг- } \\
\text { Хак }\end{array}$ \\
\hline Волк & 5 & - & - & - & - & - \\
\hline Корсак & - & - & - & 1 & - & - \\
\hline Кулан & 40 & - & 4 & 2 & 1 & 3 \\
\hline Лошадь & 2 & - & - & - & - & 3 \\
\hline Верблюд & - & - & - & - & - & 1 \\
\hline Крупный бык & 4 & 1 & 2 & 2 & 1 & 3 \\
\hline Сайгак & 7 & 1 & 5 & 7 & 1 & 30 \\
\hline Овца & - & - & - & 2 & 1 & 4 \\
\hline Всего особей & 58 & 2 & 11 & 14 & 6 & 44 \\
\hline
\end{tabular}

Примечания. Зональная приуроченность видов животнық. С т - степные, Ст-в - степные околоводные. ПП - полупустынные, пф - псаммофиты, с - обитатели суглинистых, глинистых и плотных песчаных субстратов. Ст-ПП - степно-полупустынные. П - пустынные, пф и с - те же, что и для ПП, П-в - пустынные мезофилы. Э - эвризональные, обитающие от лесов до пустынь. Ст, ПП, П - степно-полупустынно-пустынные виды. Д - домашние. В - водные.

Самарский научный вестник. 2014. № 3(8)
Таблица 3 - Изменение состава животного мира Рын-песков в голошене 「141

\begin{tabular}{|c|c|c|c|c|c|}
\hline \multirow{3}{*}{ Виды } & \multirow{3}{*}{$\begin{array}{l}\text { 3ональная } \\
\text { прнурочен- } \\
\text { ность } \\
\text { вддов }\end{array}$} & \multicolumn{4}{|c|}{$\begin{array}{l}\text { Соотношение минимального числа особей (по трем } \\
\text { археологическим памятникам) }\end{array}$} \\
\hline & & \multirow[t]{2}{*}{\begin{tabular}{|l|}
$\begin{array}{l}\text { Bcero } \\
\text { особ̆ей }\end{array}$ \\
\end{tabular}} & \begin{tabular}{|l|} 
AT-2, \\
поздний неолит, \\
$6,5-6$ т.л.н.
\end{tabular} & \begin{tabular}{|l} 
АТ-3, \\
поздний \\
энеолит, 5,2 \\
5 т.л.н.
\end{tabular} & $\begin{array}{l}\text { SB-2, } \\
\text { средняя } \\
\text { бронза, 2-3 } \\
\text { века между } \\
4-3,6 \text { т.л.н. }\end{array}$ \\
\hline & & & \multicolumn{3}{|c|}{$\begin{array}{l}\text { Соотношения, \%: числитель - для внда, } \\
\text { знаменатель - для эпохи }\end{array}$} \\
\hline $\begin{array}{l}\text { Грызуны: } \\
\text { Желтая пеструшка }\end{array}$ & ПП-пф & 130 & $6 / 46$ & $79 / 60$ & $14 / 14$ \\
\hline Степная пеструшка & $\mathrm{CT}_{\mathrm{T}}$ & 16 & $7 / 6$ & $37 / 3$ & $56 / / 6$ \\
\hline Полевки (microtus) & $\mathrm{C}_{\mathrm{T}}$ & 16 & $37 / 3$ & $37 / 3$ & $63 / 6$ \\
\hline Водяная полевка & CT-B & 2 & 0 & $100 / 1$ & 0 \\
\hline Обыкновенная слепушонка & 3 & 6 & 0 & 0 & $100 / 4$ \\
\hline Серый хомячок & $\mathrm{C}_{\mathrm{T}}$ & 4 & 0 & $58 / 1$ & $50 / 1$ \\
\hline Хомячок Эверсмана & $\mathrm{CI}_{\mathrm{T}}$ & 2 & 0 & $100 / 1$ & 0 \\
\hline Мальй суслик & ППन-в & 3 & 0 & $100 / 1$ & 0 \\
\hline Желтый суслик & ПП-пф & 2 & 0 & $100 / 1$ & 0 \\
\hline Гребенщиковая песчанка & П-пф & 64 & $6 / 24$ & $38 / \mathbf{1 4 , 6}$ & $56 / \mathbf{2 3}$ \\
\hline Полуденная песчанка & $\overline{\Pi-n \dot{\phi}}$ & 54 & 0 & $11 / 3$ & $89 / 29$ \\
\hline Краснохвостая песчанка & П-в & 3 & 0 & $100 / 2$ & $100 / 8$ \\
\hline Большой тушканчик & $\mathrm{C}_{\mathrm{T}}$ & 2 & 0 & $100 / 1$ & 0 \\
\hline Малый тушканчик & 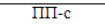 & 2 & 0 & $100 / 1$ & 0 \\
\hline Тарбаганчик & $\Pi-c$ & $\frac{2}{3}$ & 0 & 0 & $92 / 8$ \\
\hline Домовая мышь & 3 & 13 & 0 & $8 / 0,6$ & 0 \\
\hline $\begin{array}{l}\text { Хищные: } \\
\text { Собака (?) }\end{array}$ & д & 1 & $100 / 6$ & 0 & - \\
\hline Kopсak & $\mathrm{Cr}, \mathrm{MI}$ & 1 & 0 & $100 / \mathbf{0 , 5}$ & 0 \\
\hline $\begin{array}{l}\text { Парнокопытные: } \\
\text { Баран }\end{array}$ & д & 1 & $100 / 6$ & + & + \\
\hline $\begin{array}{l}\text { Насекомоядные: } \\
\text { Пегий путорак }\end{array}$ & $\Pi-c$ & 1 & 0 & $100 / 0,6$ & 0 \\
\hline $\begin{array}{l}\text { Земноводные: } \\
\text { Жабы (?) }\end{array}$ & Э-в & 7 & 0 & $71 / 3$ & $29 / 1$ \\
\hline $\begin{array}{l}\text { Рыбы: } \\
\text { окуневые (?) }\end{array}$ & $\mathrm{B}(\mathrm{Cr})$ & 3 & $67 / 12$ & $33 / \mathbf{0 , 6}$ & 0 \\
\hline $\begin{array}{l}\text { Молуюски: } \\
\text { пресноводные (перловнца?) }\end{array}$ & $\mathrm{B}(\mathrm{Cr})$ & $\frac{5}{6}$ & 0 & $33 / 1$ & $67 / 3$ \\
\hline Учтено відов & & 22 & 6 & 18 & 11 \\
\hline Минимальное чпсло особей & & 351 & 17 & 175 & 159 \\
\hline Всего костей & & 1079 & 136 & 609 & 334 \\
\hline
\end{tabular}

Особенности экологических условий в эпоху неолита

На территории модельного участка обнаружено 22 местонахождения с археологическими находками эпохи неолита. В отличие от мезолита на половине объектов неолита сохранились культурные слои с погребенными почвами. Археологически выделены три хроноэтапа неолита. Ранний (памятник Кугат), длительностью около 500 лет, 14С-датирования не проводилось. Средний неолит, каиршакский этап (памятники Каиршак-1, 3, 4, 6, 7), 14С даты - 6,7 и 6,9 т.л.н. Поздний неолит, тентексорской этап (памятники Же-Калган-1, 3, Тентексор-1, Комбакты, Курпеже-Молла-1), 14С даты - 6 и 6,5 т.л.н.

Ранний неолит. Ориентировочно 8-7,5 т.л.н. Развитие ландшафтов Рын-песков происходило в изменяющихся климатических условиях. Формирование почв конца бореала (мезолита) было прервано дефляционными процессами начала раннеатлантического подпериода в раннем неолите. Эти почвы прикрыты маломощными (до 0,5 м) эоловыми песками (до 0,5\% $\mathrm{CaCO}_{3}$ ) с косой слоистостью или без нее. Условия почвообразования в раннем неолите, длившегося около 500 лет, оцениваются, как близкие к nустыннылм. Уровень Каспийского моря регрессивный. Археологически инвентарь с памятника Кугат близок к памятникам мезолита. Всего к раннему неолиту отнесены 2 памятника из 22-х, плотность памятников на 100 лет эпохи равна 0,4.

Средний и поздний неолит, 7, 5 - 6 т.л.н.

Палинологические данные [13; 23] характеризуют АТ-1 - АТ-2 как теплую, относительно сухую эпоху с преобладанием полыней, маревых. Ю.А. Лаврушин с соавторами истолковывают зональное положение этого времени как пустынное-полупустынное, Н.С. Болиховская - как полупустынное-сухостепное.

Почвы среднего и позднего неолита изучены на 4-х памятниках.Показано их раразвитие в условиях колебательного увеличения увлажнения из бурых пустынно-степных почв в каштановидные почвы. Рассмотрим свойства почвы позднего неолита на примере $p .1$ археологического памятника Тентексор-I . Памятник расположен в песчаном массиве к востоку от крупного одноименного сора, на ровной площадке у окраины котловины выдувания. Площадка сохранилась от выдувания вследствие уплотненности горизонта А погребенных почв. На поверхности этого частично дефлированного горизонта встречены многочисленные обломки керамики, в том числе крупные развалы сосудов, каменные орудия. Почву перекрывает эоловый нанос мощностью 
0,8 м. Разрез, заложен в 15 м от края раскопа поселения, где погребенная почва менее повреждена и уходила под эоловый нанос.

Диагенетическими чертами являются уменьшение содержания гумуса из-за его минерализации в интервале 10-31 см, увеличение содержания гумуса в слое 0-10 см (гор.А), как части системы насыпь - гор.А, окарбоначенность гор.А, A/B, В до $1 \% \mathrm{CaCO}_{3}$ (ниже содержание $\mathrm{CaCO}_{3}$ уменьшается до 0,2-0,5\%).

Исходными чертами почвы эпохи неолита можно считать строение их профиля (реконструкция): $\mathrm{A} 1_{\mathrm{z}}-\mathrm{A} /$ $\mathrm{B}_{\mathrm{z}}-\mathrm{B}_{\mathrm{z}}-\mathrm{BC}_{\mathrm{ca}}-\mathrm{D}_{\text {cas.Fe }}$, мощности горизонтов (pис.11), карбонатность горизонтов ВС и CD (до 4,6\% CaCO), биогенность (крупнопористость) гор. $\mathrm{A}, \mathrm{A} / \mathrm{B}_{z}, \mathrm{~B}$. В профиле отмечено образование органо-минеральных $(\mathrm{Fe})$ пленок. Исходное вскипание почвы, вероятно, неблюдалось с глубины $115 \mathrm{~cm}$.

Почва времени позднего неолита археологического памятника Же-Калган-I имеет некоторые отличительные особенности. Ее поверхность была к моменту погребения сильнее дефлирована (наличие «заструг» на поверхности), мощность горизонта А в связи с этим уменьшилась примерно на 10 см. Горизонты имеют меньшие мощности, проработке деятельностью мезофауны подвергся только горизонт А. Вместе с тем профиль ее лучше гумусирован $(0,7-0,8 \%)$, слабее окарбоначен.

Почвы развитого и позднего неолита эволюционировали от бурых пустынно-степных к каштановидным маломощным в условиях постепенного колебательного улучшения увлажнения климата. В позднем неолите они были в целом достаточно гумусированными (содержали более $1 \%$ гумуса), гумусовый горизонт был проработан мезофауной. Выветривание минералов и лессиваж были мало интенсивными. Аккумуляция карбонатов происходила в нижней части профиля (от 0,5 до 4,6\% $\mathrm{CaCO}_{3}$ ). Легкорастворимые соли выносились за пределы профиля. К концу неолита почвы приобрели свойства и облик дерново-степных каштановидных маломощных почв, формировавшихся в условиях подзон светло-каштановых - каштановых почв.

Особенности расселения древнего человека, хозяйствования и взаимодействия человека с природой в неолите. В связи с улучшением природных условий (сухие степи) численность населения в Рын-песках возросла, достигнув 0,6-1 тыс. человек (плотность 0,06-0,1 чел/км²). По мнению И.Б. Васильева, развитие культур также продолжалось на местной основе. Основным региональным влиянием было кавказско-причерноморское; среднеазиатское прослеживается слабо. Количество одновременно существовавших поселений на территории модельного участка достигало 4-10 единиц. Средние расстояния между поселениями при такой плотности расположения составляли около 30-40 км, реально, вероятно, и меньше, т.к. поселения располагались в наиболее удобных для жизни и охоты местах, число которых было ограничено. Это создавало возможности взаимодействия между «родами» и «семьями», способствуя формированию единой культуры. Места проживания жителей развитого и позднего неолита представляли собой настоящие поселения. На сохранившихся от дефляции раскопанных участках обнаружено по 2 жилища на поселении. Ясно, что на поселениях их было больше, вероятно, от 5 до 10. Жилища были заглублены на несколько десятков см, имели над котлованами какие-то шатровые перекрытия. Котлованы достигали размеров до 9 м в поперечнике, площади - 50$80 \mathrm{M}^{2}$. В таких жилищах могли жить семьи численностью 10-15 человек. Намечается разделение жилищ на хозяйственную и жилую части, в них имеются очаги с прокалами, золой, углями, жжеными костями. В жилищах и вокруг них на территории поселения встречается немало хозяйственных ям.

В жилищах, на поселениях и стоянках обнаружено большое количество лепных глиняных сосудов, обжигавшихся на кострах. 15-20\% от обшего числа сосудов 112 имели отверстия, просверленные после обжига. На памятнике Кара-Худук найдено целых сосудов или обломков от них 264 экземпляра, Каиршак - около 200, Тентексор - 140. Отдельные сосуды достигали объема 6-7 литров. Несомненно, что они имели многоцелевое назначение и не в последнюю очередь использовались для варки и последующего хранения мясной пищи, для чего, вероятно, часть хозяйственных ям могла использоваться в качестве погребков.

В эпоху неолита в Рын-песках использовались кремневые орудия, широко распространены изделия из кости. На памятниках обнаружено большое количество настоящих стрел. К концу неолита появляются крупные кремневые орудия - ножи, скребки, вкладыши, более удобные для разделки туш и обработки шкур диких животных. Среди кремневых находок немало нуклеусов, что свидетельствует об изготовлении части орудий на месте. Кремень и кварцит, использовавшиеся при их изготовлении, добывались в крыльевых частях соляных куполов, выходящих на поверхность (г. Богдо у озера Баскунчак; купола Азгир и другие, находящиеся в Рын-песках).

В хозяйстве неолитических племен жизни ведущая роль принадлежала охоте, определенное значение имело собирательство и рыбная ловля, т.е. тип хозяйства был в основном присваивающим. Население было оседло-кочевым.

Доказательством ведущей роли охоты является наличие большого количества костей, частично расколотых, у одного из жилищ памятника позднего неолита Тентексор. По заключению И.Е.Кузьминой (1988), они принадлежат следующему минимальному количеству особей животных: кулан - 40, лошадь - 2, крупный бык - 4, сайгак - 7. Только от этого количества животных могло быть получено не менее 10240 кг живого веса, а фактически не менее 15 тонн. Такого количества мяса 10-15 жителям одного жилища хватило бы на 1-3 года, что свидетельствует о стационарности поселения, а также о значительных масштабах охоты. Достоверность этих выводов возрастает в связи с тем, что размеры животных эпохи неолита (кулан, сайгак), по заключению И.Е.Кузьминой (1988), были большими примерно на 1/3. Если предположить, что упомянутое количество особей относится к одному жилищу, а всего жилищ на поселении могло быть от 5 до 10, то охотники одного поселения за 1-3 года добывали не менее 200-400 голов куланов, 20-40 голов быков, 35-70 голов сайгаков. Всего количество куланов, добытых обитателями 4-10 поселений на модельном участке Рын-песков, могло достигать 1000-4000, возможно, и более голов, что составляло до 2,5-10\% от общей численности их популяций . Охота таких масштабов оказывала регулирующее воздействие на численность, а еще больше на поведение куланов. Во всяком случае, в энеолите доля костей куланов среди костных остатков резко уменьшилось (количество особей куланов - до 4-6), а сайгака - возрастает (до 31 особи). Интенсивная охота на куланов в энеолите и возрастание численности домашнего скота привели к вытеснению части поголовья куланов на восток и юго-восток в менее освоенные человеком территории Казахстана и Средней Азии.

Определенная роль в хозяйственной деятельности племен эпохи неолита принадлежала рыбной ловле. А.И.Дмитриевым (1985) на поселении Тентексор были обнаружены кости рыб (окуневые). Это же может свидетельствовать о существовании пресных озер на территории.

В неолите Рын-песков происходит зарождение скотоводства [16]. Была одомашнена собака.

Особенности экологических условий в эпоху энеолита, 6-5 т.л.н. АT $^{3}$ подпериод.

Обнаружено 30 местонахождений-археологических памятников, в том числе 10 с сохранившимися культурными слоями и погребенными почвами (Курпежемолла-1, Кара-Худук, Каиршак-6, Кызыл-Хак-1 и др.). Самарский научный вестник. 2014. № 3(8) 
Изучены 6 разрезов, в 2-х проведены химико-аналитические и микроморфологические исследования.

Эоловые наносы, погребающие почвы, имеют мощность от 25 до 160 см (средняя - около 1 м). Наносы представляют собой пачку желтых косослоистых и неслоистых тонкозернистых песков различной степени окарбоначенности, иногда значительной (до $1,6 \% \mathrm{CaCO}_{3}$ ), образовавшихся в раннесуббореальном подпериоде.

Контакт эоловых желтых песков с гор. А погребенной почвы серого цвета всегда хорошо заметен вследствие цветовых различий. Поверхность погребенных почв в большинстве случаев имеет мелкоребристый характер вследствие дефляции.

Погребенная почва - p.1-Досанг (Курпеже-Молла-1).

Реконструированный профиль энеолитических почв имеет следующее строение: $\mathbf{A}_{\mathbf{z}}-60$ A/B -90 В BC - 175, C - co $175 \mathrm{~cm}$.

В гор. А происходило слабое накопление гумуса (современное содержание 0,6-0,9\%, исходное 1-2\%), образование органо-минеральных пленок, оструктуривание и биогенные процессы, формировался поглощающий комплекс (емкость поглощения 6-7 мг-экв/100 г), насыщенный кальцием. Горизонт был промыт от карбонатов, гипса и легкорастворимых солей. Происходило относительно интенсивное выветривание тонкого песка и пыли.

Гор.А/B характеризуется теми же процессами, но несколько меньшей интенсивности, усиленное почвообразование наблюдается в затеках, формирующихся в зоне скопления корней. В горизонте ослабляется образование органо-минеральных пленок и формируеются железистые пленки на песчаных зернах.

Гор.В формирования железистых пленок на зернах, вымыты гипс и легкорастворимые соли.

Гор.ВС $\mathrm{Ba}_{\text {ca }}$ - наиболее интенсивное в профиле, но в общем слаб̆ое биогенно-иллювиальное карбонатонакопление $\left(\mathrm{CaCO}_{3}, 1,2-1,4 \%\right)$.

Гор.С и D - порода без заметных признаков почвообразования, иногда с яркими чертами водного происхождения или былого гидроморфизма (ржавые пятна соединений $\mathrm{Fe}^{3+}$, темно-фиолетовые пятнышки соединений $\mathrm{Mn}^{+3,+4}$ ).

Свойства почв энеолита свидетельствует об их сходстве с черноземовидными почвами - по гумусированности, мощности гумусового профиля, величине емкости поглощения, проработанности деятельностью мезофауны, интенсивности процессов выветривания, содержанию питательных веществ $\left(\mathrm{P}_{2} \mathrm{O}_{5}, \mathrm{~K}_{2} \mathrm{O}\right)$. Однако, наличие у этих почв аккумулятивных карбонатных горизонтов $\mathrm{B}_{\text {са }}$ и $\mathrm{BC}_{\text {са }}$ позволяет отнести их к каштановидным почвам, переходным к черноземовидным, формировавшимся в условиях, переходных к черноземной зоне, т.е. близких к подзоне темно-каштановых почв. В связи с этим атмосферная увлажненность эпохи энеолита может быть оценена как большая по сравнению с современной примерно на 100 мм.

Особенности расселения древнего человека, хозяйствования и взаимодействия человека с природой в энеолите. 6,5-5 т.л.н. Рын-пески представляли собой сухие песчаные степи с лучшей, по сравнению с современной увлажненностью, обводненностью (обитатели Рынпесков добывали рыбу и моллюсков), некоторые соры были пресными озерами, продуктивность пастбищ была более высокой. Уровень Каспийского моря был трансгрессивным (Гоусанская трансгрессия).

Природно-климатические условия атлантического времени не были абсолютно однородными и стабильными. Происходили циклические изменения погодно-климатических условий различной длительности и сложности. По палеопочвенным и палинологическим данным намечаются несколько аридных хроноинтервалов длительностью до 200 лет. Назовем их, следуя А.В.Виноградову и Э.Д.Мамедову (1991), микроаридами. Они могли наблюдаться около 5400, 5700, 6000 Самарский научный вестник. 2014. № 3(8)
6500, 7100 лет тому назад (Лаврушин и др.,1991).

Археологические культуры энеолита Рын-песков по мнению И.Б. Васильева представляют собой непосредственное развитие местных неолитических культур с четко выраженными кавказско-причерноморскими чертами.

В энеолите произошел постепенный, в 1,5-2 раза рост численности населения (1-2 тыс. чел.) на территории модельного участка по сравнению с неолитом. Расцвет энеолита в Рын-песках связан с относительным улучшением экологических условий в это время. Количество атмосферных осадков увеличилось не менее чем на 100 мм, а почвы были каштановидными, близкими к черноземовидным. Это привело к повышению фитопродуктивности экосистем не менее, чем в 1,4-1,7 раза по сравнению с полупустынными.

На территории модельного участка, вероятно, могло единовременно существовать 10-20 поселений. Характер жилищ на них несколько изменялся. В отличие от эпохи неолита, отсутствуют котлованы. Жилища представляли наземные постройки шатрового типа, в них имелись очаги, зольники, грунты, насыщенные пережженными костями, а вокруг поселений - большое количество хозяйственных ям.

Как и в эпоху неолита, на поселениях-стоянках энеолита встречается от 20 до 110 сосудов, но несколько меньше, чем в неолите. Отдельные сосуды также крупные - диаметром до 45 см, высотой до 60 см, объемом до 8-9 литров. Сосуды, как правило, орнаментированы и большей частью плоскодонные. В энеолите продолжают использоваться каменные орудия. Возрастает удельный вес и количество изделий из кварцитов. По-видимому, материалов из кремня становится недостаточно. В хозяйстве используются для обработки шкур крупные кварцитовые и кремневые скребки. При охоте начинают широко применяться двусторонне обработанные наконечники стрел, появляются треугольные и черешковые наконечники. Применяются изделия из кости (проколки и какие-то другие остроконечные предметы).

Помимо керамической посуды и каменных орудий отмечены и такие изделия, как каменный пест, пряслице из обломка керамики (ритуальное изделие, зачатки ткачества ?), обломок булавы, скребки из раковин (Unio).

Энеолит Рын-песков, как отметил И.Б. Васильев, настоящий медно-каменный век. Меди немного: в углу одного из жилищ обнаружен небольшой слиток меди, в жилищах и погребениях, наряду с мелкими бусинками из раковин, встречаются и цилиндрические - из меди. Изделия из меди еще очень редки, они используются в качестве украшений и предметов культа.

Минимальное количество особей, подсчитанное по костям на памятнике Кызыл-Хак-I, показывает, что живой вес этих животных составляла свыше 6 тонн (реально не менее 10 тонн). Если принять за домашних животных только лошадь и овцу, то соотношение живой биомассы диких и домашних животных составит соответственно 79 и $21 \%$. Из этих цифр можно заключить, что доля домашних животных по числу особей составляла $20-30 \%$.

И.Б. Васильев хозяйство эпохи энеолита оценил как подвижно-кочево-скотоводческо-охотничье с рыболовством и собирательством. Для прилегающих районов степи и лесостепи у синхронного и более позднего населения вполне доказано существование производящего скотоводческого хозяйства. Население хвалынской культуры развитого энеолита разводило крупный и мелкий рогатый скот, лошадей, свиней. В.П. Шилов [24] для степей юга Европейской России наметил следующие типы скотоводческих хозяйств: 1) подвижные скотоводы, разведение овец - Нижнее Поволжье; 2) оседлые скотоводы, разведение крупного рогатого скота и свиней - Северный Кавказ, майкопская культура; 3 ) кочевые овцеводы ямной культуры - Северное Причерноморье; 4) оседлые коневоды - репинская культура, Средний Стог; 5) оседлые скотоводы, крупный 
рогатый скот - михайловская культура. Для подвижных скотоводов Нижнего Поволжья Н.Я.Мерперт [25] приводил следующее соотношение поголовья скота: овца $75 \%$, корова $-10 \%$, лошадь $-5 \%$.

Природа и человек в Рын - песках за последние 5 тысяч лет.

Дальнейшее развитие общества в Рын-песках происходило, как и ранее, в тесной зависимости от крупномасштабных изменений климатических и конкретных погодных условий. Большая часть из этого времени условия оставались зональными полупустынными Наиболее контрастные изменения отмечались для следующих эпох.

Период ранней бронзы представлен культурами «ямно-репинской», переходной по природным условиям к энеолиту, и ямной («городцовской»), примерно 4-5 т.л.н. На 100 л. эпохи приходится 0,4 памятника развеяных стоянок. Уровень Каспийского моря регрессивный $(-35$ м), ландшафтные условия близки к пустынным Эоловые отложения косослоистые, содержат детрит раковин, котловины выдувания глубокие. Население немногочисленное, периодически отсутствовало.

Период средней бронзы (примерно 4-3,6 т.л.н.). дискуссионный в археологическом и природном отношении. Число памятников, которые И.Б. Васильев отнес к полтавкинской культуре, - наибольшее за весь голоцен -35 или 8/100 л. эпохи. Встречено 4 памятника с культурными слоями и почвами. Почвы черноземовидные, соответствующие количеству осадков 300-400 Mм/ год. Мы назвали его полтавкинским микроплювиалом. По данным Н.С. Болиховской отложения палинозонь 7а содержат наибольшее количество пыльцы мятликовых, спор мхов, хвощей и папортников, минимальное количество полыней и маревых. Уровень моря в первую половину периода поднялся до -20 м (туралинская трансгрессия). Дискуссионность вопроса заключается в отсутствии 14С-дат для почв данного периода и в повышенном увлажнении песков во время аридной эпохи в степях Восточной Европы.

$B$ раннее средневековье Рын - пески были повидимому безлюдными. Памятников времени хазар и огузов (1,5-0,8 т.л.н., 5-12 в.н.э.), поздних кочевников здесь не встречено. Для Севера Западной Европы раннее средневековье известно как теплое «время викингов» или « малый климатический оптимум». В степях и полупустынях оно проявилось аридизацией вследствие роста испаряемости. Каспийское море находилось в состоянии дербентской регрессии, природные условия Рын-песков были, повидимому, близки пустынным.

Позднее средневековье известно в Европе как время похолодания, «малая леднивовая эпоха». В 13-16 веках н.э. климат степей был более влажным (+30$50 \mathrm{Mм} /$ год), продуктивность пастбищ и пашен - более высокой. Начался подъем уровня Каспийского моря (позднедербентская трансгрессия), природные условия были переходными от сухих степей к полупустынным. Местонахождения археологических находок времени Золотой Орды и Астраханского ханства встречаются относительно часто (5/100 лет эпохи).

Букеевская Орда. В 1801 - 1900 годах на территории песков и прилегающей с севера глинистой полупустыни располагалась ханство Букеевская орда - вассал Росии в составе Астраханской губернии. Орда до 1876 года управлялась местными ханами, затем управление перешло к царской администрации. В 1801-1803 г.г., когда Рын-пески были заселены казахами-кочевниками (около 50000 человек с 200000 скота), экологическое состояние было хорошим, до 30\% плошадей были покрыты лесными зарослями и кустарниками. Закрепленная за Ордой территория стала анклавом, изолированным административными границами от рек Волги и Урал и каспийского побережья. За первые 30 лет происходил бурный рост населения и поголовья скота, которое достигло 5,5 млн. голов к 1830 годам, что примерно в 5 раз превысило экологические возможности пастбищ (1-1,5 млн. голов). Известно, что в 1840 г. численность населения увеличилась по сравнению с начальной в 3 раза (до 150000 человек), а население перешло к полуоседлому образу жизни. Нарастала перегрузка пастбищ, увеличивалась площадь разбитых песков (от 0\% в момент заселения, 20\% -в 1860-х годах, $60-85 \%$ - в 1890-1930 годах, 25\% - к 1950 годам). Движущиеся пески наступали на поселки вдоль р. Ахтубы, заносили железную дорогу. Кризис перевыпаса, отчуждение до 80-90\% фитопродукции, ухудшение качества пастбищ, уничтожение лесов и кустарников, отсутствие сенокошения, впоследствии недостаточные запасы сена, катастрофические последствия погодных явлений (джуты, снегопады, пересыхание колодцев) затрудняли жизнь в песках. В частности, при джутах, повторявшихся 1 раз в 3-4 года, погибало по 500000 и более голов скота. Кроме того собирали свою смертельную жатву и периодически возникавшие эпидемии чумы. Начиная с 1880-х годов казахское население, особенно молодежь, для того что бы выжить устремилось на рыбные и соляные промыслы, в промышленность. Государственные мероприятия по облесению и закреплению песков, начавшиеся с 1890 годов и продолженные при советской власти, противочумные мероприятия во многом нормализовали положение. Эпопея жизни букеевцев в Рын-песках отражена в научных и публицистических работах А. Харузина, Г.И. Лакина, М.А. Орлова, Б.Н. Семевского, М.С Буяновского и многих других $[1 ; 5 ; 6$; 26 ] и других. Последний экологический кризис в Рынпесках (1970-1990-е гг.) связан с разведкой и начальным периодом освоения крупнейшего Астраханского серогазо-кондесатного месторождения (дорожная дефляция, дестабилизация недр, радиоактивное и химическое загрязнение) [27].

Материалы по Букеевской орде в концентрированном виде отражают экологические проблемы Рынпесков.

\section{СПИСОК ЛИТЕРАТУРЫ}

1. Иванов И.В. , Васильев И.Б. Человек, природа и почвы Рын-песков Волго-Уральского междуречья в голоцене. М.: Интеллект. 1995. 258 с.

2. Хабаров А.В. Генезис песчаных почв суббореальных пустынь и полупустынь // Почвоведение. 1994, №8. C.15-23.

3.Трушковский А.А. Почвенные образования на эоловых песках Прикаспийской низменности между реками Волгой и Уралом // Генезис и классификация полупустынных почв. М.: Наука, 1966. С.167-221.

4. Якубов Т.Ф. Песчаные пустыни и полупустыни Северного Прикаспия. М.: АН СССР, 1955. 532 с.

5. Гаель А.Г. Пески Волго-Уральского междуречья и возможность их закрепления и облесения // Пустыни СССР и их освоение. М.-Л.: АН СССР, 1954. Т.II. С.430-448.

6. Гаель А.Г. Материалы к истории освоения песчаных степей в связи с дефляцией и развитием почв на разновозрастных наносах песка // Проблемы изучения истории современных биогеоценозов. М., 1984. С.122-170.

7. Смирнова Л.Ф., Петрова Н.И., Кочерьян В.М. Распространение, свойства и генезис песчаных почв России // Почвоведение, 1994. №11. С.118-128.

8. Лавров А.П. О почвах песчаных пустынь Средней Азии // Особенности песчаных почв и их использование. М.: Наука.1979. С. 55-91.

9. Мокроусов Н.Я., Яковлев М.Г. О некоторых особенностях размещения и колебаний численности полуденной песчанки в различных частях ареала в связи с эпизоотологией чумы // Экология млекопитающих и птиц. М.: Наука, 1967. С.145-153.

10. Дмитриев А.И. Желтый суслик Волго-Уральского междуречья в голоцене // Зоологический журнал. 1981. T.IX. C.945-949.

11. Ралль Ю.М. В мире песков. Записки натуралиста. Самарский научный вестник. 2014. № 3(8) 
М.: МОИП, 1949. 106 с.

12. Абатуров Б.Д. Млекопитающие как компонент экосистем. М.: Наука, 1984. 285с.

13. Болиховская Н.С. Палиноиндикация изменения ландшафтов Нижнего Поволжья в последние 10 тысяч лет // Каспийское море. Вопросы геологии и геоморфологии. М.: Наука, 1990. С.52-68

14. Дмитриев А.И. Формирование фауны грызунов Северного Прикаспия в верхнечетвертичное время. 1985. 32 с. / Приложение в книге: Иванов И.В. , Васильев И.Б. Человек, природа и почвы Рын-песков Волго-Уральского междуречья в голоцене. М.: Интеллект. 1995. С.217-234.

15. Шадрухин А.В., Козин Е.В., Барынкин П.П., Иванов И.В. Голоцен юго-западного Прикаспия. Саратов, 1991. С. 184. /Депонированная монография № 2644 - В91. Решение Уч. Совета НИИ геологии при СГУ от 22 марта $1991 \Gamma$.

16. Кузьмина И.Е. Млекопитающие Северного Прикаспия в голоцене // Археологические культуры Северного Прикаспия. Куйбышев, 1988. С.173-188.

17. Мелентьев А.Н. Мезолит Северного Прикаспия (памятники сероглазовской культуры) //Краткие сообщения Института археологии АН СССР. №149. М.: Наука.1977. С.58-62.

18. Климанов В.А. Климат малого климатического оптимума на территории Северной Евразии //Доклады Академии наук.1994. Т.335. №2. С.232-236.

19. Виноградов А.В., Мамедов Э.Д. Первобытный Лявлякан (древнейшие этапы освоения и заселения Кызыл-Кумов). М.: Наука, 1975. 287 с.
20. Борзенкова И.И. Изменения климата в кайнозое. СПб., 1992. 247 с.

21. Варущенко А.Н., Варущенко С.И., Клиге Р.К. Изменения уровня Каспийского моря в позднем плейстоцене голоцена // Колебания увлажненности АралоКаспийского региона в голоцене. М., 1980. С.79-90.

Рычагов Г.И. Уровенный режим Каспийского моря за последние 10 тысяч лет // Вестник МГУ. География. 1993. №2. С.38-49.

22. Карпычев Ю.А. Периодичность колебаний уровня Каспийского моря по данным радиоуглеродного анализа новокаспийских отложений // Водные ресурсы. 1994. №4/5. C.415-421.

23. Лаврушин Ю.А., Спиридонова Е.А., Сулержицкий Л.Д. Геолого-палеоэкологические события севера аридной зоны в последние 10000 лет // Проблемы древней истории Северного Прикаспия. Самара, 1998. С. 40-65.

24. Шилов В.П. Модели скотоводческих хозяйственных областей Евразии в эпоху энеолита и раннего бронзового века //Советская археология, 1975, №1. С. 5-10.

25. Мерперт Н.Я. Древнейшие скотоводы ВолжскоУральского междуречья. М.: Наука, 1974. 173 с.

26. Динесман Л.Г. Изменение природы СевероЗапада Прикаспийской низменности. М.: АН СССР, 1960. $160 \mathrm{c}$.

27. Голубов Б.Н. Последствия техногенной дестабилизации недр астраханского газоконденсатного месторождения в зоне подземных ядерных взрывов // Геоэкология. 1994. №4. С.25-42.

\title{
PALEOECOLOGICAL HABITAT CONDITIONS OF THE NEOLITHIC AND BRONZE AGE TRIBES IN THE SANDS OF THE VOLGA-URAL INTERFLUVE
}

(C)2014

\author{
I.V. Ivanov, Doctor of Geographical Sciences \\ Institute of physicochemical and biological problems of soil science RAS, Pushchino(Russia) \\ I.B. Vasiliev, Candidate of History Sciences \\ Samara State Academy of Social Sciences and Humanities, Samara (Russia)
}

Annotation: Paleoecological conditions were reconstructed according to ancient soils, sediments, palynology and paleozoology. The nature of middle and late Neolithic Age roughly corresponded of modern semi-desert conditions, Eneolithic Age - more humid conditions of dry steppes. The development of landscapes and society in Ryn-Sands throughout the Holocene was broken-deflationary, repeatedly interrupted by periods of crises of aridization of the climate with active Eolian processes.

Keywords: Neolithic Age; Eneolithic Age; palaeoecology; paleo soil; broken-deflationary development of nature and society.

\section{УДК 902.6}

(C) 2014

\section{РАДИОУГЛЕРОДНОЕ ДАТИРОВАНИЕ ДРЕВНЕЙ КЕРАМИКИ}

M.A. Кулькова, кандидат геолого-минералогических наук, доцент кафедры геологии и геоэкологии Российский государственный педагогический университет им.А.И.Гериеена, С.-Петербург (Россия)

Аннотация: В статье рассматриваются проблемы радиоуглеродного датирования древней керамики. На примерах ранненеолитической керамики из памятников Восточной Европы обсуждаются основные вопросы, возникающие при радиоуглеродном датировании органики из керамики. Рассмотрены проблемы, связанные с различными источниками углерода в керамической матрице, методы пробоподготовки и влияние резервуарного эффекта на датирование.

Ключевые слова: неолит; радиоуглеродное датирование керамики; резервуарный эффект; конвенционное датирование; $\mathrm{AMC}$; технология изготовления керамики.

Радиоуглеродное датирование древней керамики является ценным методом для исследования как в радиоуглеродном анализе, так и в археологии. Время изготовления и использования древних керамических изделий соответствует времени существования древних людей. Это наиболее массовый материал, который находят при раскопках неолитических стоянок. Различные органические материалы, используемые для радиоуглеродного датирования, такие, как уголь, кости, древесина, почвы, не всегда относятся к тому же самому археологическому контексту или культурному слою, что и археологические находки. Время их существования может отличаться от времени находок материальной культуры, найденных вместе с ними, так как, например, органические остатки могут попасть в культурный слой в результате более поздних процессов переотложения и т.Д. В то же время керамика является прямым свидетельством времени существования древних людей и индикатором 